\author{
M.A. Uaikhanova ${ }^{1, *}$, S.V. Olenev ${ }^{2}$, S.Zh. Yergaliyeva ${ }^{3}$ \\ ${ }^{I}$ S. Toraighyrov Pavlodar State University, Pavlodar, Kazakhstan; \\ ${ }^{2}$ Kemerovo State University, Kemerovo, Russia; \\ ${ }^{1}$ S. Toraighyrov Pavlodar State University, Pavlodar, Kazakhstan \\ (E-mail:mira.p2011@mail.ru, stanislav.olenev@gmail.com,samal17.12@mail.ru)
}

\title{
Text Derivative Description of Political Discourse (based on the example of Kazakhstani Internet comments)
}

\begin{abstract}
The proposed article is devoted to the study of political Internet comments published on Kazakhstani sites. The text of a political article has a potential of derivational functioning, which is realized in the text of an online commentary and is objectified in it under influence of variable strategies and tactics. The purpose of the study is to determine the textual parameters of the text generation of Kazakhstani political Internet comments in the linguistic-personalological aspect. In the course of linguistic analysis, the following methods were used: linguistic description, derivatological analysis technique, sampling method. The study is based on a model of the text-derivatological analysis of derivative texts, which are considered in the formal, substantial and functional plans. As a text-derivative analysis' result of political Internet comments, the text parameters of the text generation were identified. The result of text-derivatological and linguoculturological research showed that Kazakhstani Internet comments are dominated by a text strategy.
\end{abstract}

Keywords: text derivatology, text factors, political text, Internet commentary, virtual linguistic personality.

\section{Introduction}

In the modern anthropological and social dimension, language is viewed through the prism of human life as a phenomenon that exists in various (social, historical, communicative, economic, etc.) contexts. Therefore, in modern linguistic science, the discursive approach to the language study becomes relevant. In particular, today political discourse is the object of integrative (interdisciplinary) research, since various sciences representatives are engaged in the study of this phenomenon.

Political linguistics appeared at the intersection of linguistics and political science, the tasks of which are solved through language, since any political action is carried out using linguistic means. In the process of vigorous activity of mass communication, language becomes an instrument of influence and manipulation. Using a language, one can influence its carrier, use it as an instrument of categorization, as well as an understanding of political phenomena $[1 ; 5]$.

\section{Literature Review}

The purpose of political discourse is, first of all, the struggle for power (E.I. Sheigal, A.N. Baranov, O.L. Mikhaleva, A.P. Chudinov, V.E. Chernyavskaya, E.V. Budaev) with its inherent stages: the implementation of ideas, the emotional impact on the citizens' consciousness, the incitement to political movements, the adoption of socio-political decisions, etc.

Until the second half of the 20th century, political discourse was considered mainly in the framework of rhetoric, political issues were covered in journalism, where social and political discussions of various political trends were held [2]. They are currently being discussed through the media on various portals and sites. A modern approach to the study of the manipulative - the properties of political discourse emanating from certain political tasks - and analysis of its impact on the addressee through the specific use of linguistic means by the participants in communication is presented in the work of O.L. Mikhaleva. The main goal of this discourse is the struggle for power, aimed at stimulating, informing the participants in communication (addressee (speaker), direct addressee (listener), addressee-observer (people)) through various communication means (choice of strategy and tactics) [3; 43-44].

In connection with the determination of the strategy and tactics influencing communication participants. V.E. Chernyavskaya notes that any «choice of a word not only reflects the difference in ratings

*Corresponding author's e-mail: mira.p2011@mail.ru 
(positive or negative), in emotions, but is also able to impose on others a certain attitude to the message content, then there is to direct and control perception and understanding» [4;12]. In his work, the researcher uses the terms «suggestiveness» and «persuasiveness.» In its interpretation, persuasiveness (persuasion) is the author's influence through oral or written communication with the aim of convincing his addressee in something, calling for specific actions or decisions, that is, mental-verbal influence on the recipient's consciousness with the help of communicative strategies. Suggestiveness (suggestion) is understood as a hidden effect on the addressee [4]. Given the manipulative nature of political discourse, we can confidently say that persuasiveness and suggestiveness are its features.

In political communication, unlike other types of communication, the subject of speech activity is usually representatives of some political organization or government apparatus, who pursue their own interests, manipulate the consciousness of the people with the help of their statements and speeches, use a variety of linguistic means to gain trust people, to influence the political mood in society. A.P. Chudinov distinguishes the following types of antinomies inherent in political communication: ritualism and informational content; institutional and personal character; esotericity and general accessibility; reductionism and completeness of information; standard and expressiveness; dialogic and monologous; clear and hidden appraisal; aggressiveness and tolerance [2; 71].

According to researcher B.A. Akhatova, «politics is perceived and interpreted through speech, through which politicians inform, hide true goals, convince, recommend, comment, manipulate and manage. Therefore, any speech is somehow politically loaded...» [5; 5]. Also, when studying political discourse, the relationship between language and consciousness is taken into account; intentions of participants, their status-role relations; value orientations; emotional condition; cultural specificity and many other characteristics of the socio-situational and communicative plan $[5 ; 6]$. It reveals the features of Kazakhstan's political discourse, analyzes the communicative and manipulative ways of influencing the consciousness of the people, also determines the factors that shape the political images, the forms of expression of the linguistic consciousness of Kazakhstanis and the communicative tactics used during election campaigns.

Another important feature of political discourse is metaphor, which is an effective way of emotional impact on the addressee, and also reflects the estimated picture of the political situation of the country. The metaphor has become one of the main tools for expressing political concepts that affect the consciousness of its listener, in addition, it enriches and decorates the politician speech, and is also a «natural way of creative thinking» $[4 ; 122]$.

Three types of information are most often transmitted using metaphors: subjective-evaluative (containing a pronounced assessment of the subject of speech on an object or phenomenon), modally imperative (transmitting the volitional attitude of the subject of speech), emotional (expressing the emotional state of the subject of speech). When transmitting information, the subject resorts to using a metaphor to solve his own problems, in particular, to impose his opinion on the addressee, for example, exaggerates or understates the significance of an event or offers a biased, favorable assessment of phenomena. And in order to achieve an effective result, the subject uses stylistically colored language means.

In the understanding of R.I. Zaripov, «a metaphor is not only a figurative figure of rhetoric or poetics, but an interpretive, epistemological category that has a creative role in structuring and revealing the world, in some cases it serves as a deliberate distortion means of reality» [6; 47]. So, the metaphorical nature of political texts is formed by stylistically colored linguistic means, reconstructs vivid and memorable images that are fixed in the mind of the recipient.

One of the frequently encountered methods of influencing public consciousness is the contrasting of the «own / own» and «alien / alien» parameters $[4 ; 7 ; 8 ; 9 ; 10 ; 11]$. If the speaker has the task of persuading the interlocutor to his side, forcing him to think and act according to the proposed plan, then he begins to introduce into the interlocutor's mind the idea that «he thinks and speaks as many, and many speak and think like him.» The researcher calls this technique «creating his own» semantic field [4; 48]. To create a field, personal and possessive pronouns are used: «we», «ours», «you», «you», «your» (choice), «your» (duty); name of the addressee by personal name. An effective way to control the recipient's consciousness is to present information on the plus or minus principle, that is, when «own / own» is opposed to «stranger / stranger» [4; 51-52].

Thus, when thinking, «a reaction of consciousness to what is happening in the form of modal actions takes (I agree) / I do not accept (doubt)» [9; 50], that is, an assessment arises - approval or disapproval, 
which contributes to the generation and execution of thought. The researcher considers the opposition of thoughts as a sociopsychic reaction to what is happening.

Today the attention of linguists is not only the political communication of public figures or organizations that manipulate the consciousness of the people, but also speech activity and the linguistic consciousness of unprofessional communicants of political discourse. [12; 48].

As Professor A.P. Chudinov notes, «every person who even reads newspapers occasionally, turns on the radio or television, becomes the addressee of political communication» [2; 6]. He believes that political communication not only informs, but also affects his addressee emotionally, thereby contributing to the transformation of the political world picture in human consciousness.

Ordinary linguistic consciousness manifests itself in the interpretation of political discourse, since it is in the comments that reflect the subjective representations of the recipients based on their life values. When perceiving and interpreting the primary political text, the addressee creates his own model of the text containing evaluative elements, with the help of which the awareness of textual information and the relation to the described political events and realities are explicated [13; 77].

According to researcher B.A. Akhatova, the study of political discourse takes into account the relationship between language and consciousness; intentions of participants, their status-role relations; value orientations; emotional condition; cultural specificity and many other characteristics of the socio-situational and communicative plan $[5 ; 6]$.

S.I. Agagyulova understands by linguistic consciousness the part of personality consciousness that provides the mechanisms of speech activity, linguistic consciousness is studied through the semantics of linguistic units that materialize it in the process of nomination and communication [14; 4]. Linguistic consciousness is investigated using an associative experiment, which helps to identify the nature of the interaction of linguistic units in various processes of speech activity. In linguistics, linguistic consciousness is subdivided into ordinary (everyday) and professional (scientific). The first type of linguistic consciousness, based on common sense, everyday experience, reflects social life superficially, taking into account only its external, random signs. The second type reflects the professionally-oriented part of consciousness, which consists of a set of cognitive formations, that is, knowledge, opinions, impressions arising in the professional field [14;6-7].

Thus, political discourse is a linguistic-political action aimed at the implementation of certain goals and realized in a different space of being, therefore, the object of research can be both a newspaper text, an oral statement, and texts on the Internet, and political figures can become participants in political communication, but also ordinary citizens who are interested in political events and are producers of oral and written texts immersed in the political sphere.

Internet comments, being secondary texts, realize the derivational potential of the source text. This is proved by the fact that it is Internet comments that contain mutational innovations that indicate a change in the internal form of the text, its functional orientation.

The object of the study is the texts of Kazakhstani political Internet comments.

The purpose of the study is to determine the textual parameters of the text generation of Kazakhstani political Internet comments in the linguistic-personalological aspect.

\section{Materials and Methods}

Materials for this study were based on the texts of Kazakhstani Internet commentaries which were left to the articles of political subjects located on the information portals Nur.kz, Newtimes.kz, Zakon.kz, Total.kz, Dixinews. In the course of linguistic analysis, the following methods were used: linguistic description, derivatological analysis technique, sampling method.

\section{Results and Discussion}

The conducted linguistic analysis was based on the model of text-derivative analysis developed by N.V. Melnik [15], which helped to determine personal and textual factors of text generation of Kazakhstani political Internet comments. Further, the method of introspection and contextual analysis of texts contributed to the identification of text generation parameters within personal and textual factors. Using this model, the parameters of the textual factor of the text generation of Internet comments were revealed. A brief description of the parameters for producing Internet comments can be seen in the following scheme. 
Scheme 1.

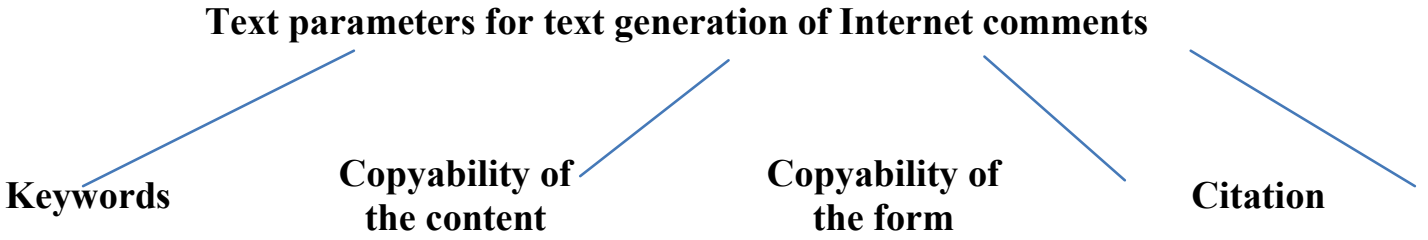

1. Parameter of keywords. Let us present a comment on the text «Zachem Nazarbaev priezzhal v Almatinskuyu oblast'» (Why Nazarbayev came to the Almaty region) from the news portal Nur.kz. The source text describes the President's working trip to the Almaty region and his visit to various places. Subsidirovanie gosudarstva - eto ochen' vazhno. Odnoznachno. Eto takoe delo-budut den'gi, budet $i$ proizvodstvo. Kak zhe horosho vyglyadit Elbasy! Kak horosho chto u nego stol'ko energii na postoyannye poezdki i rukovodstvo (State subsidies are very important. Definitely. This is such a thing - there will be money, there will be production. How good Elbasy looks! It's good that he has so much energy for constant trips and leadership). The presence of keywords - subsidies, the state, travel, production - conveys both external and internal links with the source text, which indicates the objectivity of the text generation of Internet comments. The commentary focuses on a specific fragment of the source text, on the quote from the President: Osnovnoj posyl vsekh moih obrashchenij $k$ agrariyam zaklyuchaetsya $v$ neobhodimosti subsidirovaniya proizvoditel'nosti truda, to est', sredstva budut vydelyat'sya na proizvodstvo gotovogo produkta (The main message of all my appeals to farmers is the need to subsidize labor productivity, that is, the funds will be allocated for the production of the finished product). There are linguistic units from the quoted fragment in the commentator's text. It replaces the keywords labor productivity with the word state, and as a result, the phrase «subsidizing the state» is obtained, which absolutely does not change the essence of the fragment of the source text. We can say that the submitted Internet commentary is produced under the influence of textual factors. The derivation process that has taken place has led to a change at the level of surface structures, therefore we attribute this innovation to a modification type.

2. Parameter of copyability of the content. The parameter of copyability of the content is done by sending the content of the source text by the Internet commentators with the help of indirect deployment or reduction of thoughts, substitution of the keywords with synonyms or other linguistic (variational) means which are chosen by the virtual linguistic person during commenting on the political problem.

Let us consider the comment on the article «Nýrsýltan Nazarbaev nazval sobytiia v Almaty teraktom» (Nursultan Nazarbayev called the events in Almaty a terrorist attack) from the news portal Dixinews in the Kazakh, which reflects the use of the parameter of copyability of the content. Imandy bolsyn, ózimiz bir birimizdi qyryp ne bolyp bara jatyr sonsha?! Aqylǵa keleiik! (Rest in peace! Who are we turning into killing each other?! Let's be reasonable!). As you can see, in the secondary text there are no primary keywords. The text undergoes a derivative process, contains mutational innovation. First of all, it is produced in another language, which means that the vocabulary does not coincide in the form of the text. But the very essence of the commentator's text conveys the topic, the content of the article through descriptions. Therefore, this comment reflects the textual potential.

3. Parameter of copyability of the form. Let us analyze the comments on the previous political text.

Kanat Ote auyr zhazdaj. Almaty ķalasy ķajzydan қan zhłtyp otyr! (A very serious case. Almaty is drowning in blood!).

Kuanysh Kanshama otbasy əkesin zhoķtap kajzydan "қan zhłtyp otyr». Memleket tarapynan komek kersetip, oz ķamқ̧orlaryнyzza alsa dejmin. ZHandaryn zhənnatta bolsyn. Skol'ko sem'ej, oplakivaya otcov, zahlebyvayutsya $v$ krovi. Hotelos' by, chtoby gosudarstvo pomoglo im i vzyalo pod svoyu zashchitu. Pust' dushi ih popadut $v$ raj (How many families, mourning their fathers, are drowning in blood. I would like the state to help them and take them under their protection. May their souls go to heaven). Paying attention to the formal, informative and functional outline of the texts, it is easy to notice that the commentator under the nickname Kuanysh copies the key phrase kan zhytyp otyr (chokes in the blood) of the commentator's text Kanat, expanding his statement on this issue. The phrase copied and highlighted with quotes is the key phrase; it contains the whole meaning of the commentator's text under the name Kanat; this indicates the preservation of the content, that is, a formal-semantic connection with the motivating text.

4. Parameter of citation. This parameter is implemented with the help citation tactics in the source text. The author, without changing, copies a fragment of the source text or uses the entire text of the interloc- 
utor to express his thoughts, intentions as an additional bet. Commentator reaction left to political text «Tenge ýkrepilsia posle oslableniia» (Tenge strengthened after weakening) from the news portal Zakon.kz. «Tenge ýkrepilsia posle oslableniia» Ýh ty aj na tselyh dve tenge ýkrepilsia! Teper Ia skazochno bogat! («Tenge strengthened after weakening» Wow, it strengthened by two whole tenge! Now I am fabulously rich!). The author, commenting on the political text, quotes the title of the article and interprets it: Teper Ia skazochno bogat! (Now I am fabulously rich!). The text is obviously negatively colored, ironic and even sarcastic. In this way, the author shows his attitude to the title of the text and the problem stated in it. The exclamation mark used by the commentator enhances the emotional expressiveness of the text. Observations allow us to conclude that the commentary was created through the tactics of citation of the text factor.

Conclusions. A linguistic analysis of Internet comments by users of news portals belonging to active participants in the discussion of political events shows that the linguistic personality, its choice of strategies and tactics of speech production are significant factors in building virtual communication. Comments and the source text do not always coincide in content, which indicates the role of subjective factors in creating the secondary text, the text of the original political article has the potential for derivational development, but choice of the way of its implementation depends on the commentator's preference to use personal or textual text generating tactics. So, the results of text-derivative analysis of derivative texts, involving the study of secondary texts for N.V. Melnik's classification of the parameters of the content, form and function of the secondary text, helped to identify and establish that the listed parameters: keywords, copyability of the content, copyability of the form, citation reveal the textual potential of Kazakhstani political Internet comments.

Thus, according to the results of a linguistic analysis of political Internet comments, the following were revealed:

- textual parameters of the text generation of political Internet comments;

- parameters of the text factor - keywords, copyability of the content, copyability of the form, citation;

- the presented conclusions of the linguistic analysis are connected with the everyday political consciousness of an ordinary native speaker, in which their life experience, images of their thinking, national identity, level of political awareness are manifested.

This article was supported by a grant from the MES RK, project AP08053314 «Problem of a valuable national picture formation of the world in the context of society and the state modernization (based on the material of Kazakhstan's ordinary political discourse)».

\section{References}

1 Баранов А.Н. Политический дискурс: методы анализа тематической структуры и метафорики / А.Н. Баранов, О.В. Михайлова, Г.А. Сатаров, Е.А. Шипова. — М.: Фонд «ИНДЕМ», 2004. — 94 с.

2 Чудинов А. П. Политическая лингвистика: учеб. пос. / А. П. Чудинов. - М.: Флинта; Наука, 2006. - 256 с.

3 Михалева О. Л. Политический дискурс как сфера реализации манипулятивного воздействия: моногр. / О. Л. Михалева. - Иркутск: Иркут. ун-т, 2005. - 320 с.

4 Чернявская В. Е. Дискурс власти и власть дискурса: проблемы речевого воздействия: учеб. пос. / В. Е. Чернявская. - М.: Флинта; Наука, 2006. - 136 с.

5 Ахатова Б.А. Политический дискурс и языковое сознание: моногр. / Б.А. Ахатова. - Алматы: Экономика, 2006. $302 \mathrm{c}$.

6 Зарипов Р. И. Метафорическое моделирование образа России в современном французском политическом дискурсе: моногр. / Р. И. Зарипов. - М.: Р. Валент, 2016. - 220 с.

7 Алиева Т.В. Концептуальная оппозиция «свой - чужой» в политическом дискурсе Великобритании (Великобритания - США) / Т.В. Алиева // Вестн. Тамбов. ун-та. — Вып. 11 (67). - Тамбов: Изд-во ТГУ, 2008. — С. $216-220$.

8 Кишина Е.В. Семантическая оппозиция «свой - чужой» как реализация идеолого-манипулятивного потенциала политических дискурсов / Е.В. Кишина // Вестн. КемГУ. — № 4 (48). — Кемерово, 2011. — С. 174-179.

9 Краснова Т.И. Анализ политического дискурса: подходы и категории / Т.И. Краснова // Политическая лингвистика, Гл. ред. А.П. Чудинов. — № 2(44). — Екатеринбург: ФГБОУ ВПО «Урал. гос. пед. ун-т», 2013. — С. $46-54$.

10 Савельева И.В. Вариативность стратегий текстовосприятия и текстопорождения: лингвоперсонологический аспект (на материале текстов политических интернет-комментариев): дис. ... канд. филол. наук: 10.02 .01 - «Русский язык» / И.В. Савельева. - Кемерово, 2013. - 251 с.

11 Балашова Л.В. Реализация концептов «свой - чужой» в российском политическом дискурсе начала XXI века / Л.В. Балашова // Политическая лингвистика / гл. ред. А.П. Чудинов. — Екатеринбург: ФГБОУ ВПО «Урал. гос. пед. ун-т», 2014. - Вып. 1 (47). - С. 40-50. 
12 Чудинова А.П. Имплицитные и эксплицитные стратегии в восточно-европейском политическом дискурсе / А. П. Чудинова, Э. В. Будаева. - Екатеринбург, 2014. - 198 с.

13 Буракова О.В. К вопросу об отражении обыденных оценочных представлений в политической коммуникации (на материале анализа текста политического содержания) / О.В. Буракова // Обыденное метаязыковое сознание и наивная лингвистика: сб. науч. ст. / отв. ред. Л.Г. Ким. - Кемерово, 2012. - С. 76-82.

14 Агагюлова С.И. Концепт «Интернет» в обиходном и профессиональном языковом сознании: автореф. дис. ... канд. филол. наук: 10.02.19 - «Теория языка» / С.И. Агагюлова. — Волгоград, 2010. — 22 с.

15 Мельник Н.В. Деривация русского текста: Лингвистические и персонологические аспекты / Н. В. Мельник. - М.: ЛЕНАНД, 2014. — 280 с.

\title{
М.А. Уайханова, С.В. Оленев, С.Ж. Ергалиева \\ Саяси дискурстың мәтінсөзжасамдық сипаттамасы (қазақстандық интернет-түсіндірме мысалдары негізінде)
}

\begin{abstract}
Мақалада қазақстандық сайттарда жарияланатын саяси интернет-түсіндірме мәтіндері зерттелген. Саяси мақалалар мәтіндерінің сөзжасам әлеуеті интернет түсіндірмелерде өзгермелі стратегиялар мен тактикалар арқылы жүзеге асып, көрінеді. Зерттеудің мақсаты - лингвоперсонологиялық аспектіде қазақстандық саяси интернет-түсіндірмелердің мәтіндік мәтінсөзжасамы параметрлерін анықтау. Лингвистикалық талдау барысында мынадай әдістер қолданылды: лингвистикалық сипаттама, дериватологиялық талдау әдістемесі, іріктеу әдісі. Зерттеу мәтін тудырушы мәтінсөзжасам талдауының моделі негізінде жүргізілген. Саяси интернет-түсіндірмелердің мәтінсөзжасамдық талдау нәтижесінде мәтінсөзжасамының мәтіндік факторының параметрлері анықталған. Мәтінсөзжасам және лингвомәдениеттік зерттеу нәтижесі бойынша қазақстандық интернет-түсіндірмелерінде мәтіндік стратегия басымдылығы байқалды.
\end{abstract}

Кілт сөздер: мәтінсөзжасамы, мәтіндік факторлар, саяси мәтін, интернет-түсіндірме, виртуалды тілдік тұлға.

\author{
М.А. Уайханова, С.В. Оленев, С.Ж. Ергалиева
}

\section{Текстодериватологическое описание политического дискурса (на примере казахстанских интернет-комментариев)}

\begin{abstract}
Статья посвящена исследованию текстов политических интернет-комментариев, публикуемых на казахстанских сайтах. Текст политической статьи обладает потенциалом деривационного функционирования, который реализуется в тексте интернет-комментария, опредмечивается в нем под влиянием вариативных стратегий и тактик. Цель исследования - определить текстовые параметры текстопорождения казахстанских политических интернет-комментариев в лингвоперсонологическом аспекте. В ходе проведения лингвистического анализа были использованы следующие методы: лингвистическое описание, методика дериватологического анализа, метод выборки. Исследование базируется на модели текстодериватологического анализа производных текстов, которые рассматриваются в формальном, содержательном и функциональном планах. В результате текстодериватологического анализа политических интернет-комментариев были выявлены параметры текстового фактора текстопорождения. Результат текстодериватологического и лингвокультурологического исследования показал, что в казахстанских интернет-комментариях доминирует текстовая стратегия.
\end{abstract}

Ключевые слова: текстодериватология, текстовые факторы, политический текст, интернеткомментарий, виртуальная языковая личность.

\section{References}

1 Baranov, A. N. (2004). Politicheskii diskurs: metody analiza tematicheskoi struktury i metaforiki [Political discourse: methods for analyzing the thematic structure and metaphor]. Moscow: «INDEM» Foundation [in Russian].

2 Chudinov, A. P. (2006). Politicheskaia linhvistika [Political linguistics: a training manual]. Moscow: Flinta; Nauka [in Russian].

3 Mikhaleva, O. L. (2005). Politicheskii diskurs kak sfera realizatsii manipuliativnoho vozdeistviia [Political discourse as a sphere of implementation of manipulative influence]. Irkutsk [in Russian].

4 Chernyavskaya, V. Ye. (2006). Diskurs vlasti $i$ vlast diskursa: problemy rechevoho vozdeistviia [Discourse of power and power of discourse: problems of speech exposure]. Moscow: Flinta; Nauka [in Russian]. 
5 Akhatova, B. A. (2006). Politicheskii diskurs i yazykovoe soznanie [Political discourse and linguistic consciousness]. Almaty: Ekonomika [in Russian].

6 Zaripov, R.I. (2016). Metaforicheskoe modelirovanie obraza Rossii v sovremennom frantsuzskom politicheskom diskurse [Metaphorical modeling of the image of Russia in modern French political discourse]. Moscow: R. Valent [in Russian].

7 Alieva, T.V. (2008). Kontseptualnaia oppozitsiia «svoi - chuzhoi»v politicheskom diskurse Velikobritanii (Velikobritaniya — SSHA) [Conceptual opposition «friend or foe» in the political discourse of Great Britain (Great Britain — USA)]. Tambov: TSU [in Russian].

8 Kishina, E.V. (2012). Linhvokonfliktolohicheskii aspekt opisaniia obydennoi linhvopolitolohii [Linguoconflictological aspect of the description of everyday linguopolitology]. Kemerovo [in Russian].

9 Krasnova, T. I. (2013). Analiz politicheskoho diskursa: podhody i katehorii [Analysis of political discourse: approaches and categories]. Yekaterinburg [in Russian].

10 Savelyeva, I. V. (2013). Variativnost stratehii tekstovospriiatiia i tekstoporozhdeniia_linhvopersonolohicheskii aspekt_na materiale tekstov politicheskikh internet-kommentariev [Variability of strategies of text perception and text generation: linguisticpersonal aspect (based on texts of political Internet comments)]. Kemerovo [in Russian].

11 Balashova, L. V. (2014). Realizatsiia kontseptov «svoi - chuzhoi» v rossiiskom politicheskom diskurse nachala XXI veka [The implementation of the concepts «friend or foe» in the Russian political discourse of the beginning of the XXI century]. Yekaterinburg: FSBEI HPE [in Russian].

12 Chudinova, A.P., Budaev, E.V. (2014). Implitsitnye i eksplitsitnye stratehii v vostochno-evropeiskom politicheskom diskurse [Implicit and explicit strategies in the East European political discourse] Yekaterinburg [in Russian].

13 Burakova, O. V. (2012). K voprosu ob otrazhenii obydennykh otsenochnykh predstavlenii v politicheskoi kommunikatsii (na materiale analiza teksta politicheskoho soderzhaniia) [On the reflection of ordinary evaluative ideas in political communication (based on the analysis of the text of political content)]. Kemerovo [in Russian].

14 Agagyulova, S. I. (2010). Kontsept «Internet»v obihodnom i professionalnom yazykovom soznanii [The concept of the «Internet» in everyday and professional language consciousness]. Volgograd [in Russian].

15 Melnik, N.V. (2014). Derivatsiia russkoho teksta: Linhvisticheskie i personolohicheskie aspekty [Derivation of the Russian text: Linguistic and personological aspects]. Moscow: LENAND [in Russian]. 